\title{
PENINGKATAN KECAKAPAN HIDUP (LIFE SKILL) MELALUI STRATEGI KONSTRUKTIVISME PADA MATAPELAJARAN BIOLOGI KELAS VII B SMP NEGERI 17 KOTA BENGKULU
}

\author{
Dian Anggraeni1 dan C. Darwin2 \\ ${ }_{1}$ Universitas Muhammadiyah Bengkulu \\ ${ }_{2}$ Universitas Muhammadiyah Bengkulu
}

\begin{abstract}
This study aims to determine whether constructivism strategies in biology class VII B SMP Negeri 17 Bengkulu City in 2009 Improve Life Skills. The research data consisted of teacher and student activities obtained from observation sheets and life skills sheets to see the development of students' life skills. The subjects of this study were Grade VII B students of SMP Negeri 17 Bengkulu City in 2009. This research was a classroom action research conducted in two cycles. The results of this study showed that in cycle 1 the percentage of students who lacked life skills was $12.86 \%$, students who had sufficient life skills were $5.46 \%$, students who had good life skills were $1.57 \%$, and did not there are students who have life skills very well. The average score of teacher activity is 20 (good) and the average score of student activity is 12 (good). Increase in cycle II students who lack life skills are only $2.23 \%$, students who have sufficient life skills are $7.31 \%$, students who already have good life skills are $8.91 \%$ and students who have life skills with very good is $1.8 \%$. The average score of teacher activity increased to 20.5 (good) and the average score of student activity increased to 20 (good). Based on these data it can be said that biology lessons with constructivism strategies in SMP Negeri 17 Bengkulu City in 2009 can develop students' life skills.
\end{abstract}

Keywords: Development, Life Skills, Constructivism Strategies.

Abstrak: Penelitian ini bertujuan untuk mengetahui apakah terdapat peningkatan kecakapan hidup (life skill) siswa melalui strategi konstruktivisme pada matapelajaran biologi kelas VII B SMP Negeri 17 Kota Bengkulu.Data penelitian terdiri dari aktivitas guru dan siswa di peroleh dari lembar observasi dan lembar kecakapan hidup untuk melihat pengembangan kecakapan hidup siswa. Subjek penelitian ini adalah siswa kelas VII B SMP Negeri 17 Kota Bengkulu Tahun 2019. Penelitian ini adalah penelitian tindakan kelas yang dilaksanakan dalam dua suklus. Hasil penelitian ini menunjukan bahwa pada siklus 1 persentase siswa yang kurang memiliki kecakapan hidup adalah $12,86 \%$, siswa yang memiliki kecakapan hidup yang cukup adalah 5,46\%, siswa yang sudah memiliki kecakapan hidup dengan baik adalah $1,57 \%$, dan tidak ada siswa yang memiliki kecakapan hidup dengan sangat baik. Rata-rata skor aktivitas guru 20 (baik) dan rata-rata skor aktivitas siswa 12 (baik). Meningkat pada siklus II siswa yang kurang memiliki kecakapan hidup hanya 2,23\%, siswa yang memiliki kecakapan hidup yang cukup adalah 7,31\%, siswa yang sudah memiliki kecakapan hidup yang baik adalah $8,91 \%$ dan siswa yang memiliki kecakapan hidup dengan sangat baik adalah 1,8\%. Rata-rata skor aktivitas guru meningkat menjadi 20,5 (baik) dan rata-rata skor aktivitas siswa siswa meningkat menjadi 20 (baik). Hasil penelitian menunjukkan bahwa terdapat peningkatan kecakapan hidup (life skill) siswa melalui strategi konstruktivisme pada matapelajaran biologi kelas VII B SMP Negeri 17 Kota Bengkulu.

Kata Kunci: Pengembangan, Kecakapan hidup, Strategi konstruktivisme.

\section{PENDAHULUAN}

Pendidikan adalah investasi sumber daya manusia jangka panjang yang mempunyai nilai strategis bagi kelangsungan peradapan manusia di dunia. Oleh sebab itu, hampir semua negara menempatkan variabel pendidikan sebagai suatu yang penting dan utama dalam konteks pembangunan bangsa dan negara. Begitu juga Indonesia menempatkan pendidikan sebagai sesuatu yang penting dan utama. Hal ini dapat dilihat dari isi pembukaan UUD 1945 alenia IV yang menegaskan bahwa salah satu tujuan nasional Indonesia adalah mencerdaskan kehidupan bangsa (Kunandar, 2007).

Sampai saat ini persoalan pendidikan yang dihadapi bangsa Indonesia adalah rendahnya mutu pendidikan pada setiap jenjang dan satuan pendidikan pada setiap jenjang pendidikan, khususnya pendidikan dasar dan menengah berbagai upaya untuk meningkatkan mutu pendidikan tersebut telah dan terus dilakukan, mulai dari berbagai pelatihan untuk meningkatkan kualitas guru, penyempurnaan kurikulum secara periodik, perbaikan sarana prasarana manajemen sekolah. Namun, indikator kearah pendidikan belum menunjukan peningkatan yang signifikan (Muslich, 2008).

Siswa merupakan objek yang paling penting, sebab tujuan yang harus dicapai dari proses tersebut ialah perubahan perilaku siswa. Oleh karena itu di dalam memilih dan menggunakan strategi belajarmengajar faktor siswa tidak boleh diabaikan. Setelah menetapkan strategi belajar-mengajar yang mana sebaiknya digunakan berdasarkan pertimbangan tujuan dan materi, maka di dalam menentukan 
bagaimana teknik menggunakan strategi belajarmengajar tersebut, faktor siswa menjadi salah satu pertimbangan. selain siswa dalam proses belajar mengajar seorang guru hendaklah mempunyai kesiapan mengajar dengan baik termasuk penguasaan materi dan perlu juga pertimbangan penggunaan strategi pembelajaran (Winataputra, 1999).

Permasalahan di atas dapat diatasi dengan pengembangan pendidikan kecakapan hidup (life skill). Dengan mengembangkan jenis pendidikan ini, lulusan tidak hanya terbatas dari hantu pengangguran, namun dapat hidup secara manusiawi. Kecakapan hidup (life skill) ini adalah salah satu alternatif paradigma dan orientasi pendidikan persekolahan yang di yakini dapat digunakan untuk pemecahan masalah mendasar dan kritis dari pendidikan dasar dan menengah umum di Indonesia (Irwandi, 2007).

Latar belakang ditetapkanya konsep pendidikan berorientasikan kecakapan hidup (life skill) adalah tantangan globalisasi yang menuntut kualitas sumber daya manusia yang unggul dipersaingan pasar global, rendahnya kualitas pendidikan di Indonesia dibanding negara lain, tingginya data siswa yang tidak melanjutkan kejenjang yang lebih tinggi dari semua jenjang, rendahnya daya tampung perguruan tinggi, yakni 12,6 persen, sedangkan 88,4 persen masuk dunia kerja tanpa memiliki bekal kecakapan hidup (Kunandar, 2007).

Dari hasil observasi di SMP Negeri 17 Kota Bengkulu ketuntasan belajar siswa kelas VII B pada pembelajaran Biologi secara klasikal sangat rendah dan keaktifan siswa juga sangat rendah. Ketuntasan belajar dan keaktifan siswa yang sangat rendah tentu menimbulkan banyak pertanyaan. Apakah strategi pembelajaran yang diterapkan guru kurang tepat atau siswa yang tidak memiliki kecakapan hidup yang baik.
Strategi belajar juga merupakan tindakan guru dalam melaksanakan rencana pengajaran artinya usaha guru dalam menggunakan beberapa variabel pengajaran seperti tujuan, bahan, metode, dan alat serta evaluasi agar dapat mempengaruhi siswa mencapai tujuan yang telah ditetapkan. Strategi berarti pilihan pola kegiatan belajar mengajar yang diambil untuk mencapai tujuan secara efektif. Strategi yang di gunakan meliputi beberapa masalah seperti mengidentifikasikan perubahan tingkah laku dan kepribadian peserta didik sesuai dengan tujuan yang diharapkan, memilih sistem pendekatan pengajaran, memilih dan menetapkan prosedur, metode, dan tehnik pembelajaran.

\section{METODE}

Penelitian yang dilakukan ini adalah penelitian tindakan kelas (classroom action research). Penelitian tindakan kelas ini dapat membantu dalam memecahkan permasalahan guna memperbaiki dan meningkatkan kualitas pembelajaran secara profesional. Instrumen yang digunakan dalam penelitian ini adalah instrumen non tes yaitu lembar observasi dan lembar kecakapan hidup.

\section{HASIL PENELITIAN DAN PEMBAHASAN}

\section{Hasil}

Siklus I

Aktivitas siswa selama proses pembelajaran dapat dilihat pada tabel 1 dan hasil analisis data observasi siswa dapat dilihat pada tabel berikut:

Tabel 1. Hasil Analisis Data Obsevasi Siswa dalam Proses PembelajaranPada Siklus I

\begin{tabular}{|c|c|}
\hline Pengamat & Skor \\
\hline 1 & 12 \\
\hline 2 & 12 \\
\hline Jumlah & 24 \\
\hline Rata-rata skor & 12 \\
\hline Kategori aktivitas siswa & Baik (B) \\
\hline
\end{tabular}

Dari tabel 1. Menunjukan bahwa rata-rata skor yang diperoleh dari pengamat I dan Pengamat II sebesar 12 termasuk dalam kategori Baik (B). Artinya, bahwa aktivitas siswa dalam mengikuti proses pembelajaran pada siklus I sudah baik. Walaupun demikian, masih ditemukan beberapa aspek termasuk dalam kategori kurang yang perlu perbaikan, antara lain :

a. Siswa kurang menanggapi pertanyaan motivasi siswa.

b. Siswa kurang memperhatikan guru menjelaskan materi pelajaran. c. Siswa kurang mengemukakan masalah untuk dipecahkan.

d. Siswa ada yang tidak membuat laporan dengan menghubungkan pengetahuan awal dan pengetahuan yang baru mereka dapat.

e. Siswa kurang membahas hasil diskusi.

f. Siswa tidak membuat kesimpulan berdasarkan indikator pengajaran.

\section{Kecakapan Hidup (life skill) Siswa}

Pada tabel 2 dibawah ini data mengenai jumlah dan persentase kecakapan personal. 
Tabel 2. Jumlah dan Persentase kecakapan personal

\begin{tabular}{|c|c|c|c|c|c|c|c|c|c|}
\hline \multirow{3}{*}{ No } & \multirow{3}{*}{$\begin{array}{l}\text { Indikator/ } \\
\text { pernyataan }\end{array}$} & \multicolumn{8}{|c|}{ Alternatif Jawaban } \\
\hline & & \multicolumn{2}{|c|}{ Kurang } & \multicolumn{2}{|c|}{ Cukup } & \multicolumn{2}{|c|}{ Baik } & \multicolumn{2}{|c|}{ Amat Baik } \\
\hline & & Orang & $\%$ & Orang & $\%$ & Orang & $\%$ & Orang & $\%$ \\
\hline 1 & $\begin{array}{l}\text { Kecakapan } \\
\text { menyelesaikan } \\
\text { tugas-tugas } \\
\text { pembelajaran }\end{array}$ & 10 & $29 \%$ & 19 & $54 \%$ & 5 & $14 \%$ & - & - \\
\hline 2 & $\begin{array}{l}\text { Kecakapan selama } \\
\text { proses pelajaran } \\
\text { biologi berlangsung }\end{array}$ & 15 & $43 \%$ & 14 & $40 \%$ & 3 & $9 \%$ & - & - \\
\hline
\end{tabular}

Dari tabel 4.3 diatas dapat diketahui bahwa dari masing-masing item, 35 responden yang dijadikan sampel menyatakan bahwa:

Dari data tabel diatas dapat dilihat bahwa kecakapan personal siswa dengan indikator kecakapan menyelesaikan tugas-tugas pembelajaran pada pelajaran biologi dengan strategi konstruktivisme dari seluruh siswa. 10 orang (29\%) siswa dinyatakan kurang mampu menyelesaikan tugas-tugas pembelajaran, 19 dan orang (54\%) siswa dinyatakan cukup memiliki kemampuan menyelesaikan tugas-tugas pembelajaran.

Kemudian kecakapan personal siswa dengan indikator kecakapan siswa selama kegiatan proses pelajaran biologi berlangsung dengan strategi konstruktivisme dari seluruh siswa. 15 orang $(43 \%)$ siswa dinyatakan kurang memiliki kecakapan personal selama kegiatan proses pelajaran biologi berlangsung, 14 orang (40\%) siswa dinyatakan cukup memiliki kecakapan personal selama proses pelajaran biologi berlangsung, dan 3 orang (9\%) siswa dinyatakan sudah memiliki kecakapan personal dengan baik.

\section{Pembahasan}

Peningkatan ini menunjukan bahwa strategi konstruktivisme dapat mengembangkan kecakapan hidup siswa. Hal ini sejalan dengan pendapat Depdiknas, (2002) yang mengatakan bahwa penyelenggaraan proses belajar mengajar juga perlu disesuaikan dengan tututan kompetensi kecakapan hidup, misalnya bahan ajar, guru, metode pembelajaran, media pembelajaran, fasilitas pembelajaran, tempat belajar, durasi pembelajaran, dan lingkungan pembelajaran sangat diperlukan. Mengingat siswa SLTP sudah terbiasa hidup dilingkunganya, maka sangat tepat jika "konteks" atau kancah mereka hidup dapat digunakan sebagai sarana untuk pendidikan berorientasikan kecakapan hidup. Demikian juga, interaksi guru dan siswa dalam proses belajar mengajar perlu dirancang kembali agar pemberian bekal dasar dan latihan-latihan yang dilakukan secara benar ditujukan untuk mencapai kecakapan hidup. Hal ini juga sejalan dengan pendapat Depdiknas, (2001) yang mengatakan bahwa pendidikan di negara maju kini juga mengarah kepada pembentukan kecakapan hidup (life skill). Model pembelajaran kontekstual (CTL) dan model pembelajaran terpadu merupakan model pembelajaran yang mengarah kepada pembentukan kecakapan hidup (life skill).

\section{SIMPULAN}

Berdasarkan hasil penelitian ini dapat diambil kesimpulan antara lain:

1. Penerapan strategi konstruktivisme dalam pelajaran biologi dapat mengembangkan kecakapan hidup (life skill). Peningkatan ini dapat ditunjukan dari hasil lembaran kecakapan hidup terhadap empat variabel dan sembilan indikator. Dimana pada siklus $112,857 \%$ siswa kurang memiliki kecakapan hidup dan tidak ada siswa yang memiliki kecakapan hidup dengan sangat baik, tapi pada siklus II 2,23\% siswa yang kurang memiliki kecakapan hidup dan 1,8\% siswa sudah memiliki kecakapan hidup yang sangat baik.

2. Hasil observasi dari guru dan siswa pada siklus 1 dan siklus II masuk pada kategori baik. Dimana pada siklus 1 aktivitas guru memperoleh skor 20, meningkat pada siklus II dengan skor 20,5 dengan kategori baik. Sedangkan aktivitas siswa pada siklus 1 memperoleh skor 12 dengan kategori baik, meningkat pada siklus II dengan skor 20 dengan kategori baik.

\section{DAFTAR PUSTAKA}

Djamarah, dkk. 2006. Strategi Belajar Mengajar Jakarta : Rineka Cipta.

Fathurrohma, dkk. 2007. Strategi Belajar Mengajar Melalui Penanaman Konsep Umum Dan Konsep Islam. Bandung : Refika Aditama.

Hamalik, Oemar. 2001. Proses Belajar Mengajar. Jakarta : Bumi Aksara.

Hatimah, dkk, 2007. Belajar Berwawasan kermasyarakat. Jakarta : Universitas Terbuka. 
Irwandi. 2007. Pengaruh Pendekatan Kontektual Dalam Pembelajaran Biologi Melalui Strategi Inkuiri dan Masyarakay Belajar (learning Komunity) Terhadap kecakapan Hidup (Life Skill) Siswa SMA Se-Kota Bengkulu. Laporan Penelitian. Bengkulu : LPPM Universitas Muhammadiyah Bengkulu.

Ibrahim. 2003. Perencanaan Pengajaran. Jakarta: Rineka Cipta.

Kunandar. 2007. Guru Propesional Implementasi (KTSP) Dan Sukses Dalam Sertifikasi Guru. Jakarta : Raja Grafindo Persada.

Muslich, Mansur. 2008. KTSP Pembelajaran Berbasis Kompetensi Dan Kontekstual. Jakarta : Bimi Aksara.

Mardiana. 2007. Analisis Kecakapan Berpikir Siswa Pada Pembelajaran Matematika dengan Pemberian Tugas Problem Posing Pada Pokok Bahasan Bangun Datar Di Kelas VII SMP Muhamadiyah 1 Kota Bengkulu. Skripsi.
Bengkulu : Universitas Muhamadiyah Bengkulu.

Nasution. 2005. Teknologi Pendidikan. Jakarta : Bumi Aksara.

Nurhadi, dkk. 2003. Pembelajaran Kontekstual Dan Penerapanya Dalam KBK. Universitas Negeri Malang.

Tim BBE, Depdiknas. 2001. Konsep Pendidikan Kecakapan Hidup ( life skill). Jakarta : Depdiknas.

2002. Pendidikan Berorientasi Kecakapan Hidup (life Skill) Jakarta : Depdiknas.

Winataputra, dkk. 1999. Strategi Belajar Mengajar. Jakarta : Universitas terbuka. 